\title{
PEMANFAATAN PROGRAM MAPLE DALAM PENGUATAN KONSEP SIMBOL MATEMATIKA
}

\author{
Agung Deddiliawan Ismail \\ Universitas Muhammadiyah Malang \\ deddy@umm.ac.id
}

\begin{abstract}
ABSTRAK
Matematika dan bahasa merupakan dua ilmu yang sangat berbeda satu sama lain. Walaupun demikian pada dasarnya matematika sama dengan bahasa, didalam keduanya berisi tentang kalimat. Dalam ilmu bahasa kalimat adalah serangkaian kata-kata yang terbentuk dan memiliki makna.Tidak jauh berbeda dengan matematika, di dalam matematika juga terdapat kalimat matematika yang merupakan suatu rangkaian kata atau simbol yang bernilai benar dan salah.Dalam penyusunan kalimat tersebut matematika dan bahasa memiliki aturan dalam penulisan.Ilmu bahasa memiliki aturan dalam pemilihan kata-kata yang sesuai untuk membentuk suatu kalimat yang memiliki arti.Sedangkan matematika juga memiliki aturan tertentu dalam menyusun suatu kalimat.Di dalam kalimat matematika tersebut berisi serangkaian kata/simbol yang beraturan yang memiliki makna. Sama halnya dengan bahasa, jika dalam penyusunan kaliamat tersebut tidak menggunakan kata-kata yang sesuai maka kalimat tersebut akan memiliki makna yang salah. Begitu juga dalam matematika jika dalam penggunaan aturan simbol tidak ditaati maka kalimat matematika itu akan bermakna salah.Berdasarkan pada hasil observasi yang dilakukan pada mahasiswa UMM Semester VI kelas B dengan jumlah mahasiswa sebanyak 50 orang. Terdapat beberapa kesalahan penggunaan simbol dalam menyeselsaikan suatu permasalahan matematika.Berdasarkan data awal yang dikumpulkan dapat disimpulkan bahwa mahasiswa banyak melakukan kesalahan dalam penulisan pendefinisian fungsi. 40 mahasiswa melakukan kesalahan dalam penulisan/peletakan simbol sama dengan "=" dan 30 mahasiswa melakukan kesalahan dalam penulisan/peletakan tanda bagi " $\div$ ”. Dibutuhkan suatu upaya dalam mengatasi kesalahanyang dilakukan oleh mahasiswa.Dengan menggunakan Maple, mahasiswa dibimbing untuk belajar menuliskan symbol/notasi matematika dengan benar.
\end{abstract}

Kata Kunci: maple, konsep, simbol.

\begin{abstract}
ABSTRAK
Mathematics and language are two fields that are distinguished from one another. However, both fields are similar in basic as both are talking about sentence. In linguistics, the sentence is a series of words' form and meaning. The definition is not far different from the mathematics as there is also a math sentence which is a series of words or symbols that is true and false. In the preparation of writing the sentence, Math and Language has rules. The rules of Linguistic is in the selection of the appropriate words to form a sentence that has meaning, while the mathematics also has certain rules in arranging a sentence. In the mathematical sentence, it contains a series of words / symbols regularity that has meaning. As in Language, if in the preparation of sentence is not using words that are appropriate, then the sentence will have wrong meaning. Likewise, if the use of the symbol rule is not adhered to, then the Mathematical sentence
\end{abstract}


would be false. Based on the results of observations conducted to $50 \mathrm{UMM}$ students Semester VI class B, there is some errors in the use of symbols to solve a Mathematical problem. Based on preliminary data collected, it can be concluded that the students made mistakes in the writing of the function definition. 40 students made mistake in writing / laying of the same symbols with "=" and 30 students made a mistake in writing / laying the sign for " $\div$ ". It takes an effort to solve student's mistake. By using Maple, students are guided in learning to write Math symbols / notation correctly.

Keywords : Maple, mathematics, symbols

\section{Pendahuluan}

Matematika bukan sekedar ilmu Matematika dan bahasa merupakan hitung, melainkan ilmu yang dua ilmu yang sangat berbeda satu sama mencangkup kemampuan berfikir, bernalar, mengkomunikasikan, mengaitkan pengetahuan yang satu dengan lainnya serta memecahkan masalah.Dalam matematika terdapat symbol/notasi yang memiliki peranan yang sangat penting dalam melakukan serangkaian kegiatan berfikir tersebut.

Mathematics is a symbolic language which enables to think about the quantity of the matters and to record them while they relate the thoughts and the relations between the quantities to each other

Ahmad Yarmohammadian (2014).

Symbol/notasi memiliki peranan yang penting dalam matematika. Noeryanti (2014) juga menyebutkan bahwa notasi/simbol adalah suatu alat atau perangkat untuk mengekspresikan suatu objek (benda, kalimat, bilangan dan sebagainya. 
kata-kata yang sesuai maka kalimat tersebut akan memiliki makna yang salah. Begitu juga dalam matematika jika dalam penggunaan aturan simbol tidak ditaati maka kalimat matematika itu akan bermakna salah.

Matematika juga mengajarkan bagaimana menyajikan pernyataan dalam bentuk lisan, tulisan dan symbol serta diagram. Dalam Matematika banyak sekali symbol/notasi yang digunakan sebagai alat bantu dalam melambangkan sesuatu.Dengan banyaknya symbol/notasi tersebut banyak siswa yang mengalami kesalahan dalam penulisan symbol.Berdasakan hasil penelitian yang dilakukan oleh Elbrink (2014), dapat disimpulakn bahawa salah satu keasalahan yang dilakukan dalam belajar matematika adalah pada penulisan symbol. Kesalahan banyak terjadi pada proses merubah dari suatu penyataan menjadi symbol/notasi. Penelitian ini juga sejalan dengan penelitian yang dilakukan oleh Puspadewi [5] yang menyimpulkan bahwa dalam penelitiannya mahasiswa melakukan kesalahan dalam penulisan symbol/notasi.Berdasarkan hasil yang analisis yang dilakukan pada lembar kerja mahasiswa Prodi Pendidika Matematika UMM pada mahasiswa yang menempuh matakuliah statistic terdapat banyaknya kesalahan penulisan symbol/notasi
matematika.Dari 50 mahasiswa terdapat beberapa kesalahan penggunaan simbol dalam menyeselsaikan suatu permasalahan matematika.Berdasarkan data awal yang dikumpulkan dapat disimpulkan bahwa mahasiswa banyak melakukan kesalahan dalam penulisan pendefinisian fungsi.Sebanyak 40 mahasiswa melakukan kesalahan dalam penulisan/peletakan simbol sama dengan "=" dan 30 mahasiswa melakukan kesalahan dalam penulisan/peletakan tanda bagi “ $\div$ ”.Hal inimenunjukkan bahwa terjadi suatu permasalahan berkenaan dengan symbol yang terjadi pada mahasiwa. Polya (2004) mengatakan:

A good notation should be unambiguous, pregnant, easy to remember: it should be avoid harmful second meaning, and take advantage of useful second of signs should suggest the order and connection of things.

Dimana notasi/simbol yang baik adalah tidak ambigu dan mudah diingat. Untuk mangatasi kesalahan dalam penulisan symbol/notasi tersebut maka perlu dilakukan upaya, salah satunya adalah dengan memanfaatkan kemajuan Teknologi Informasi. Maple merupakan piranti lunak yang dapat digunakan di personal computer dan tablet bersistem operasi iOS. Sehingga dapat digunakan 
dimana saja dan kapan saja.Maple adalah piranti lunak khusus untuk menyelesaikan semua permasalahan dari mulai masalah matematika sederhana sampai dengan masalah terapan.Begitu besarnya manfaat maple untuk menyelesaikan maslah matematika.Walaupun memiliki manfaat yang hebat Maple juga mempunya semua aturan dasar mengenai penggunaan simbol. Diantaranya adalah dalam penulisan definisi, simbol sama dengan dan simbol bagi. Mahasiswa diajak langsung untuk menggunakan maple untuk mendefinisikan dan menggunakan symbol yang lain. Dengan memanfaatkan dan mengaplikasikan langsung, maka mahasiswa dapat memperkuat konsep dasarnya mengenai penggunan simbol dalam matematika.Sehingga mahasiswa dapat menulisakan simbol-simbol matematika dengan benar dan tepat.

\section{Metode Penelitian}

\section{Pendekatan dan Jenis Penelitian}

Pendekatan yang digunakan dalam penelitiana adalah kualitatif.Pendekatan kualitaif adalah suatu penelitian yang mengkaji secara intensif mengenai keadaan tertentu menurut Setyosari (2013).Dan untuk lebih memperdalam hasil penelitian jenis penelitian yang digunakan adalah deskriptif.

\section{Subjek Penelitian}

Subjek penelitian yang digunakan dalam penelitian penerapan ini adalah mahasiswa UMM Semester VI kelas B yang menempuh matakuliah Statistika Inferensial sebanyak 50 mahasiswa.

\section{Hasil dan Pembahahasan}

Analisis Lembar Kerja Mahasiswa (LKM)

Kegiatan awal yang dilakukan dalam penelitian adalah analisis LKM matakuliah Statistika Inferensial.Gambar 1 dan 2 merupakan dua dari 50 LKM yang dianalisis. Terlihat bahwa kedua mahasiswa melakukan kesalahan dalam penulisan symbol $z_{\text {hitung }}$ atau $z_{\text {score }}$ dimana kata "hitung" atau "score" merupakan indeks. Selain itu penulisan sama "=" dengan yang tidak sejajar dengan tanda operasi pembagian “ $\div$ ”. Hal ini menimbulkan makna yang ambigu, diman $\quad z_{\text {hitung }}=\left(\frac{x_{1}}{n_{1}}-\frac{x_{2}}{n_{2}}\right)-$ $\left(p_{1}-p_{2}\right)$ dimana bagian ini merupakan pembilang dari rumus $z_{\text {hitung }}$. Kesalahan ini secara tidak sadar dilakukan mahasiswa dalam menyelesaikan soal Statistik. 


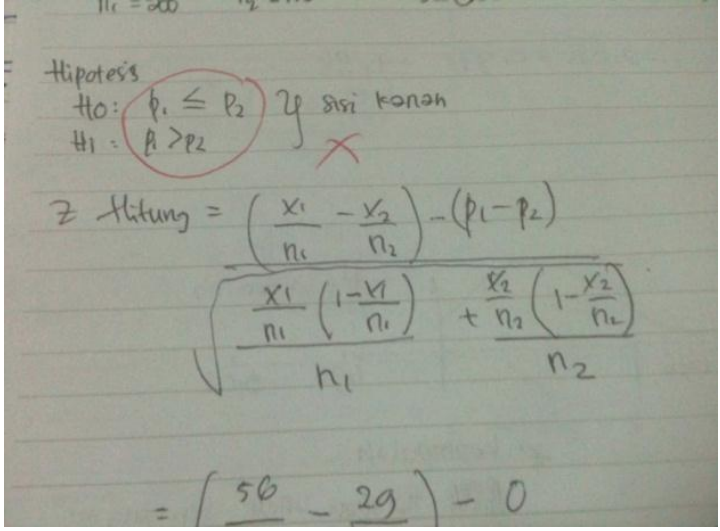

Gambar 1. Kesalahan penulisan simbol

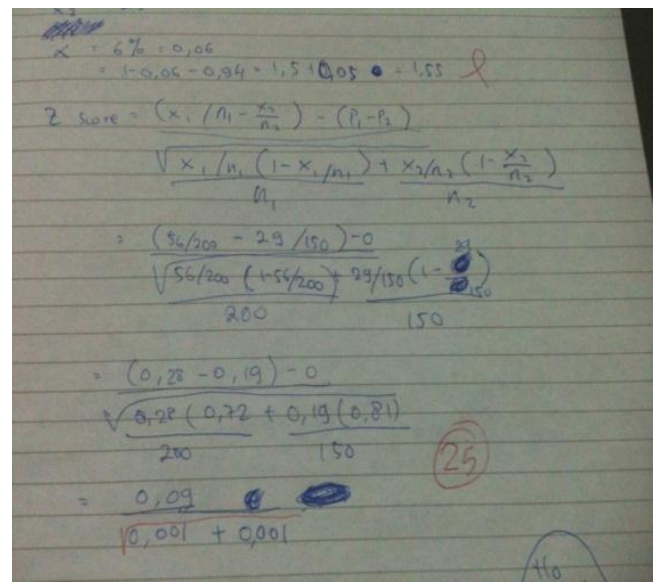

Gambar 2. Kesalahan penulisan simbol

\section{Penerapan Penggunaan Maple}

Pada awal penggunan Maple, mahasiswa sedikit dijelaskan mengenai manfaat serta interface atau tampilan dari Maple. Dimulai dari susudan menu bar, menu, toolbar danworksheet. Mahasiswa diminta untuk mencoba membuka semua menu dan tool yang ada di dalam maple.Hal ini bertujuan agar menumbuhkan rasa ingin tau terhadap Maple. Pada saat penerapan mahasiswa cenderung mencari tahu bagaimana cara menggunakan Maple dengan bantuan help. Setelah terbiasa dengan Maple, mahasiswa diajak berdiskusi mengenai kegunaan worksheet, dan menu yang tersedia di bagian kiri (Gambar. 3). Dalam diskusi ini dijelaskan pula mengenai ekpresi matematika serta symbol/notasi yang terdapat di Maple.

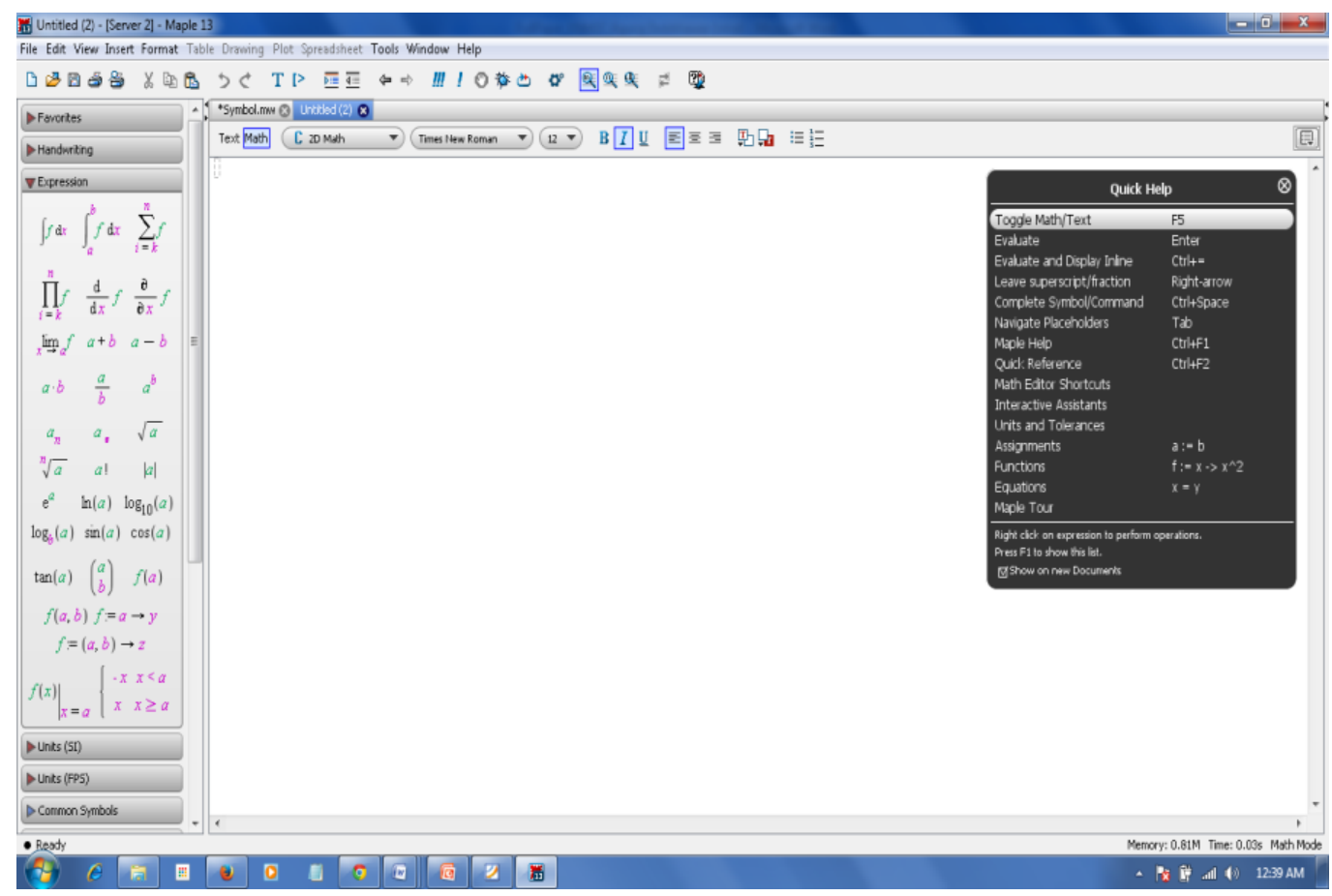

Gambar 3. Tampilan awal Maple 
Setelah terbiasa dengan Maple, mahasiswa diminta untuk menuliskan rumus $z_{\text {hitung }}$ atau $z_{\text {score }}$ di worksheet maple. Seperti terlihat pada Gambar 4.

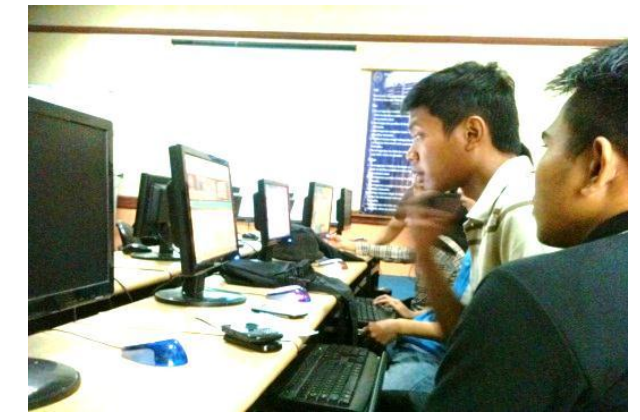

Gambar 4. Mahasiswa menuliskan rumus

$$
\begin{aligned}
& {[>\text { restart: }} \\
& z_{\text {score }}=\frac{\frac{x_{1}}{n_{1}}-\frac{x_{2}}{n_{2}}-p_{1}+p_{2}}{\sqrt{\frac{x_{1}\left(1-\frac{x_{1}}{n_{1}}\right)}{n_{1}^{2}}+\frac{x_{2}\left(1-\frac{x_{2}}{n_{2}}\right)}{n_{2}^{2}}}} \\
& >z_{\text {score }}=\frac{\left(\frac{56}{200}-\frac{29}{150}\right)-(0)}{\sqrt{\frac{\frac{56}{200} \cdot\left(1-\frac{56}{200}\right)}{200}+\frac{\frac{29}{150} \cdot\left(1-\frac{29}{150}\right)}{150}}} \\
& \begin{array}{l}
>\text { evalf }(\%) \\
=>
\end{array} \\
& z_{\text {score }}=\frac{65}{6911} \sqrt{41466} \\
& 1.915219414
\end{aligned}
$$

Gambar 5. Penggunaan Maple

Terdapat beberapa tahapan dalam penulisan rumus dalam Maple yang pertama mahasiswa menggunakan expression dalam menuliskan $z_{\text {hitung }}$ atau $z_{\text {score }}$ pada worksheet. Selanjutnya mahasiwa dapat menggunakan tanta "=" atau ":=" yang berarti sebagai istilah didefinisikan. Tahap selanjutnya mahasiswa menggunakn expression operator pembagian “ $\div ”$. Kemudian mengisi bagian pembilang yang diawali dengan menggunakan tanda kurung buka dan diikuti dengan menggunakan operator" $\div$ ”.Kemudian diisi dengan $x_{1}$ dan $n_{1}$ dilanjutkan dengan symbol pengurangan kurung tutup dan “_“. Selanjutnya menggunakan kurung buka dan 
diketikkan $\quad p_{1}$, tanda operasi pengurangan “_" dan simbol $p_{1}$. Pada penyebut terlebih dahulu menggunakan expression akar kuadrat “ $\sqrt{ }$ ", kemudian menggunakn expression operator pembagian “־”. Untuk pembilang didalam akan kembali menggunakan expression operator pembagian " $\div$ ” yang diisi dengan $x_{1}$ dan $n_{1}$, kurung buka, dan dilanjutkan dengan mengetikkan angka satu "1", operasi pengurangan “_“ serta dilanjutkan menggunakan expression operator pembagian “־”yang diisi dengan $x_{1}$ dan $n_{1}$ dan pada akhir penyebut di ketikkan $n_{1}$. Langkah selanjutnya adalah mengetikkan tanda “_“ disamping kiri setelah bagian kiri selesai. Kemudian menggunakn expression operator pembagian “ $\div$ ”. Untuk pembilang didalam akan kembali menggunakan expression operator pembagian “־”yang diisi dengan $x_{2}$ dan $n_{2}$, kurung buka, dan dilanjutkan dengan mengetikkan angka satu "1", operasi pengurangan “_“" serta dilanjutkan menggunakan expression operator pembagian “־”yang diisi dengan $x_{2}$ dan $n_{2}$ dan pada akhir penyebut di ketikkan $n_{2}$. Dan langkah yang terakhir adalah menekan tombol "enter".

Setelah selesai menuliskan rumus, mahasiswa diminta untuk memasukkan data/nilai pada rumus tersebut dan didapat hasil akhir seperti Gambar. 5. Diakhir pembelajaran mahasiswa diminta untuk membandingkan hasil kerja pada lembar kerja mahasiswa dan hasil pada worksheet Maple. Dari hasil refleksi mahasiswa menyadari bahwa dalam penulisan symbol/notasi mahasiswa mengalami kesalahan.Sehingga menyebabkan makna yang ambigu dan kesalahan dalam menemukan jawaban.

\section{Kesimpulan}

Berdasarkan hasil pengunaan Maple dalam menuliskan symbol/notasi mahasiswa menyadari bahwa dalam penulisan symbol/notasi mahasiswa mengalami kesalahan.Sehingga menyebabkan makna yang ambigu dan kesalahan dalam menemukan jawaban. Mahasiswa memgkonstruksi pemahamannya sendiri mengenai bagaimana cara menuliskan symbol yang sesuai dalam matematika. Hal ini memperkuat pemahaman konsep mahasiswa mengenai penulisan symbol.

\section{Daftar Pustaka}

Einstein, A. 1938. The Evolution of Physics: The growth of ideas from early concepts to relativity and 
quanta.New York, Simon and Schuster.

Elbrink, Megan., Analizing and Addressing Common Mathematical Errors in Secondary Education.www.bsu.edu/libraries/vir tualpress/mathexchange/05-

Ol/Elbrink.pdf(Online 15 Februari 2014)

Noeryanti, Logika

Dasar,

elista.akprind.ac.id/upload/.../3207_B

ab_1_Proposisi (Online 12 Februari 2014)

Polya, George.2004. How to Solve It.

America: Princeton University Press

Puspadewi, Kadek Rahayu.,Pengaruh

Metode Induktif Berbantuan

Asesmen Tentik Terhadap Prestasi

Belajar Aljabar Linear I Mahasiswa

$\begin{array}{lr}\text { Program Studi } & \text { Pendidikan } \\ \text { Matematika } & \text { Universitas } \\ \text { Mahasaraswati } & \text { Denpasar. }\end{array}$

lppm.unmas.ac.id/wp-content/.../9-

puspadewi-KL1.pdf (Online 5 Februari 2014).

Setyosari, Punaji.2013. Metode Penelitian Pendidikan dan Pengembangan. Jakarta: Kencana.

Yarmohammadian, Ahmad, The relationship between spatial awareness and mathematic disorders in elementary school students with learning mathematic disorder. Psychology and Behavioral Sciences.http://www.sciencepublishi nggroup.com $/ \mathrm{j} / \mathrm{pbs}$, (Online 5 Februari 2014) 